\title{
The Extract of Various Prophecies: Apocalypticism and Mass Media in the Early Reformation
}

\author{
JONATHAN GREEN
}

University of North Dakota

The compilation known as the Extract of Various Prophecies (Auszug etlicher Practica und Prophezeiungen) was the most popular prophetic pamphlet in Germany in the decade between 1516 and 1525. While the Extract was known to contain excerpts from the Prognosticatio of Johannes Lichtenberger and the Speculum of Johannes Grünpeck, this article identifies the sources of the introduction (Simon Eyssenmann's annual prognostication for 1514) and the concluding verse (an annual prognostication for 1508) and clarifies the process of compilation. In contrast to earlier views that see it as a clumsy and illogical collection of excerpts, this article finds in the Extract a coherent near-term apocalypse. Hans Stainberger, a bookseller from Zwickau, played a decisive role in the pamphlet's early dissemination, while its later circulation provides a case study in the circulation of apocalyptic ideas and the interaction between prophetic texts and prophetic preaching at the time of the Reformation.

La compilation connue comme Extraits de diverses prophéties (Auszug etlicher Practica und Prophezeiungen) consiste en un libelle prophétique, qui fut des plus populaires en Allemagne durant la décennie 1516-1525. Alors que l’on sait déjà que l'Extrait contient des extraits de la Prognosticatio de Johannes Lichtenberger et du Speculum de Johannes Grünpeck, cet article identifie les sources de son introduction - Prognostications de 1514 de Simon Eyssenmann -, ainsi que de ses versets de conclusion - Prognostications de 1508 - et contribue ainsi à clarifier le travail de compilation. Contrairement aux jugements considérant cet ouvrage comme une collection maladroite et illogique d'extraits, notre analyse y perçoit l'annonce cohérente d'une prochaine apocalypse. Hans Stainberger, un libraire de Zwickau, a joué un rôle central dans les débuts de la diffusion du pamphlet, alors que sa diffusion ultérieure représente plutôt un cas de figure pour saisir la circulation des discours apocalyptiques et l'interaction entre les textes et la prédication prophétique à l’époque de la Réforme.

\section{Introduction}

$\mathrm{I}^{\mathrm{n}}$ $\mathrm{n}$ the foreword to his novella collection Bunte Steine, the late Romantic author Adalbert Stifter responded to the criticism that he always wrote of small things and local life, and that his characters were common people. Stifter argued in his defense that small and quiet events reveal more about the great forces that govern the world than suspenseful dramas or singular cataclysms. 
Such sensations may attract the awe of children, but scholars know that there are truer and worthier objects of wonder:

If a man daily observed at predetermined times a magnetic needle whose one end always pointed north, and wrote down the changes in how the needle pointed, now more and now less directly to the north, an uninformed person would surely regard this undertaking as a trifle and a silly pastime; but how much awe and enthusiasm does this silly little game inspire when we learn that these observations are in fact taking place around the world and that the resulting tables make clear that many of the magnetic needle's small variations often take place at all points on earth simultaneously and to the same degree, that in fact a magnetic storm is extending over the whole globe, so that the entire surface of the earth feels a magnetic shudder at the same time and to the same degree. ${ }^{1}$

The study of magnetism in Stifter's time is reminiscent of Reformation-era astrology where the compilation of planetary movements enabled the accurate prediction of momentous cosmological events like eclipses, and where seemingly minute changes in the configuration of the heavens could portend the fall of kingdoms and the rise of false prophets or inspired reformers. Stifter's observation about great and small things also invites comparison with prophecy itself, a manner of speaking and a genre of writing often associated with sensational predictions and global events, thanks in part to Romantic notions of originality and genius. For prophecy in the early Reformation period, there is certainly no lack of dramatic events and striking texts; yet a clearer guide to the tectonic divides and subterranean linkages between episodic eruptions of prophetic writing and preaching might be found in the most common and seemingly unremarkable texts, in the apparently dry facts of edition history, and in the nearly imperceptible accumulation of textual variations over years and decades.

For the decade from 1516 through 1525-that is, for the last years prior to the Protestant Reformation and for the earliest years after its onset-one prophetic work stands out for its popularity: the Extract of Various Prophecies, an 
abbreviated English designation for lengthy and various original titles in German, typically taking the form Ein Auszug etlicher Practica und Prophezeiungen: Sibille, Brigitte, Cirilli, Joachim des Abts, Methodii und Bruder Reinharts; wird währen noch etliche Jahre und sagt von wunderlichen Dingen and similar. In recent scholarship, this work has sometimes been referred to inappositely as the "Anonymous Practica." The Extract is an assemblage in pamphlet form of excerpts primarily from Johannes Lichtenberger's Prognosticatio, an extensive compilation of prophecies and astrological prognostications first published in 1488. Lichtenberger's name enjoyed wide recognition in the later fifteenth century for his achievements as an astrologer and editor, but assertions that he was court astrologer to Holy Roman Emperor Frederick III are now treated with considerable skepticism, calling into question much of what was once believed about Lichtenberger as a historical person. ${ }^{2}$ The Extract supplements its borrowings from Lichtenberger with passages from more recent astrological prognostications and from the Speculum of Joseph Grünpeck, a prophetic treatise first published in 1508. Grünpeck was a scholar and humanist whose service at the court of Maximiliar I is well documented, although Grünpeck lost his position in 1501 after contracting syphilis. ${ }^{3}$

The Extract of Various Prophecies is known from fourteen editions printed between 1516 and 1525, double the number of editions of any other prophetic work in Germany during the same ten-year period (compared to seven editions of Dietrich von Zengg, six of Auffahrt Abend, and five each of Alofresant and Pamphilus Gengenbach's Nolhart, itself a dramatic reworking of Lichtenberger's Prognosticatio; all others are known in three or fewer editions). There are seven further editions of the Extract of Various Prophecies printed by 1540 and one Dutch edition (as noted below, probably to be dated ca. 1523; see the complete list of editions in the appendix). A substantial portion of the Extract moreover appears in twenty other editions of prophetic compilations throughout the sixteenth century, into the seventeenth century, and as late as 1750 .

2. Gerd Mentgen, Astrologie und Öffentlichkeit im Mittelalter (Stuttgart: Hiersemann, 2005), 227-35.

3. On Lichtenberger and Grünpeck and their works, the most comprehensive treatment is Heike Talkenberger, Sintflut: Prophetie und Zeitgeschehen in Texten und Holzschnitten astrologischer Flugschriften, 1488-1528 (Tübingen: Niemeyer, 1990), 55-145, which (in the case of Lichtenberger) builds on and updates Dietrich Kurze, Johannes Lichtenberger (†1503): eine Studie zur Geschichte der Prophetie und Astrologie (Lübeck: Matthiesen, 1960). 
The multiple editions of the Extract of Various Prophecies underscore how widespread and popular apocalypticism was in the early sixteenth century. Within a few years of its first edition, the Extract had been printed in all major centres of German-language printing except Basel. For the most broadly accessible formats-German-language quarto or octavo editions of up to thirty-two leaves-the six editions of the Extract in 1516 represent a substantial fraction of the fifty such editions known from that year. If we add to the Extract two editions of sibylline prophecies, a pamphlet on the Antichrist, and four annual prognostications, we find that prophecy, prognostication, and apocalypticism together comprise a quarter of all the German-language editions in smaller formats printed in that year.

Perhaps due to its seemingly thorough ordinariness, the Extract has been largely overlooked. The most extensive treatment remains an excursus within Heike Talkenberger's study of the flood panic of $1524 .{ }^{4}$ While Talkenberger recognized the popularity of the Extract, progress in the systematic bibliography of early printing and improved access to early editions in digital facsimile in the last few decades show that the Extract of Various Prophecies was even more popular and durable than Talkenberger thought, that its development began earlier than has been assumed, and that the dissemination of the Extract traces the contours of prophecy in the first half of the sixteenth century.

\section{Sources}

The Extract of Various Prophecies opens with a defense of astrological prediction. Not only classical authorities like Ptolemy and medieval scholars like Guido Bonatti supported astrology, according to its argument, but also church fathers like Augustine and biblical patriarchs like Abraham and Moses; not only could astrology serve the common good, but it was also endorsed by Jesus himself. Like all else in the Extract, the introduction is a borrowing rather than an original composition. Its source, previously unrecognized, is Simon Eyssenmann's annual astrological prognostication for 1514 (VD16 E 4757). ${ }^{5}$ This is the

\section{Talkenberger, $145-53$.}

5. Simon Eyssenmann, Practica Teütsch Wirckung des lauff der gestirn auf.M.d. und .xiiii. jar ([Augsburg: Johann Schönsperger the Younger], 1513), alv-a2r. Printed editions will be unambiguously identified by reference to one of the standard censuses of early printing: the Gesamtkatalog der Wiegendrucke (GW, www.gesamtkatalogderwiegendrucke.de), Incunabula Short Title Catalogue (ISTC, istc.bl.uk/search/ 
earliest recorded prognostication for Eyssenmann, a student of medicine and mathematics at Leipzig and later a professor and dean of faculty there. It would not be the only time Eyssenmann's prognostications were pressed into service under other names; his prognostication for 1515 was reprinted twice (VD16 $\mathrm{T} 1454$ and $\mathrm{T}$ 1455) but attributed to his older and more famous colleague Conrad Tockler, who at that time was at the height of his astrological career while Eyssenmann was just beginning his own. ${ }^{6}$ For the Extract, Eyssenmann's forward to his astrological prognostication was repurposed as an introduction to a compilation of late medieval prophecies.

In the Extract of Various Prophecies, the passages selected from Lichtenberger and Grünpeck have been reordered but only lightly reworded. In some cases, a brief addition between excerpts aids the transition from one passage to the next. The excerpts are not explicitly marked as borrowings from Lichtenberger or Grünpeck, but rather retain the attributions to the same prophetic luminaries that Lichtenberger had cited. The text of the Extract mentions Methodius, Cyril, and Reinhart the Lollard by name.

While Talkenberger regarded the Extract as an illogical accumulation of passages borrowed from Lichtenberger and Grünpeck, the excerpts have in fact been consciously reordered to produce a thematically coherent apocalypse. ${ }^{7}$ The basic structure consists of three parts, beginning with predictions of impending religious and political tribulation for German lands, followed by the promise of

index.html), or Verzeichnis der im deutschen Sprachbereich erschienenen Drucke des 16. Jahrhunderts and equivalent indices for the seventeenth and eighteenth centuries (VD16/VD17/VD18, www.gatewaybayern.de/index_vd16.html, www.vd18.de).

6. Friedrich Zoepfl, "Der Mathematiker und Astrologe Simon Eyssenmann aus Dillingen," Jahrbuch des Historischen Vereins Dillingen an der Donau 61/63 (1959/1961): 86-88.

7. Talkenberger, 147: "Wie aus dieser Zusammenfassung bereits ersichtlich, kann von einer logisch begreifbaren Gesamtaussage der Schrift nicht gesprochen werden, da sie lediglich additiv verschiedene Prophetienelemente aneinanderreiht" (As already apparent from this summary, there can be no talk of a logically comprehensible overall statement of this document, as it only strings together various prophecy elements additively); see also Helga Robinson-Hammerstein, "The Battle of the Booklets: Prognostic Tradition and the Proclamation of the Word in Early Sixteenth-Century Germany," in "Astrologi Hallucinati": Stars and the End of the World in Luther's Time, ed. Paola Zambelli (Berlin: de Gruyter, 1986), 136: "erratic Joachimist predictions." While Talkenberger's study was based on the then-current state of bibiliography, the scholarship is usually quite solid. The article by RobinsonHammerstein should be read with caution, however, as it was written before the sources and the genre affiliations of the Extract were clear. 
future salvation, and concluding with a note of warning directed at the present moment. Rather than being an illogical amassing of end-time motifs, it is the Extract of Various Prophecies that set about creating a unified apocalypse from the sprawling and diverse material collected in Lichtenberger's Prognosticatio.

The first set of excerpts from Lichtenberger presents an alarming view of the immediate future. Perilous times are coming, the first excerpt warns (a2r = Lichtenberger b4r), and the Extract inserts that the end of the Holy Roman Empire will entail the end of the world. ${ }^{8}$ A French usurper will overpower many Germans and will only be defeated in the end by the last world emperor $(\mathrm{a} 2 \mathrm{r}=$ Lichtenberger $\mathrm{b} 4 \mathrm{v})$. Planetary conjunctions foretell the rise of a false prophet; the Extract places his birth in the past tense and surmises that this false prophet is the current king of Persia (a2v = Lichtenberger f4r). Another conjunction points to the rise of sects, suffering for the church, the fracturing of the empire, and the advent of the Antichrist ( $a 2 v=$ Lichtenberger g5v). The Extract of Various Prophecies adds that if each planet rules for a thousand years, then 286 years remain after the year 1515 until the world's seven thousand years are complete and a purification of the world ensues. Before then, the tyrant Antichrist will darken the church and undo all who trust in him $(\mathrm{a} 2 \mathrm{v}=$ Lichtenberger b6v). In upcoming years, which the Extract specifies as 1516-18, the West will enjoy a restoration of churches lost to the Ottoman Turks and the Hussites, but eastern Europe will suffer disunity and tribulation $(\mathrm{a} 2 \mathrm{v}=$ Lichtenberger h2r). In the following years, specified in the Extract as 1522-24, western Europe will suffer pestilence, famine, harsh weather, unrest, revolt, and persecution of the clergy, a state of affairs alleviated only by the appearance of a new reformer who will restore clerical poverty ( $\mathrm{a} 3 \mathrm{r}=$ Lichtenberger $\mathrm{h} 2 \mathrm{r}$ ).

The emergence of this reformer marks the turning point in the foreseen apocalypse, as he will restore unity and proclaim new laws and a religious renewal, and the Turks will be overthrown ( $\mathrm{a} 3 \mathrm{v}=$ Lichtenberger $\mathrm{h} 2 \mathrm{r}-\mathrm{v}$ ). The Germans will rejoice, but Italy will be in turmoil, as a new king will oppress the pope and the city of Rome. The Agareni-that is, Muslim descendants of Hagar and oppressors of Christian Europe-will become subject to the Holy Roman Empire, and peace will last until 1581 (a3v-a4r = Lichtenberger h2v). All kingdoms who wage war against the German Israelites will be destroyed,

8. Citations from the Extract of Various Prophecies refer to the 1516 edition of Erhard Oeglin (VD16 A 4441). Citations of Lichtenberger refer to the first German edition (ISTC il00210000/GW M18242) of the Prognosticatio ([Heidelberg: Heinrich Knoblochtzer, 1490]). 
and Maximilian will receive divine aid in his struggles $(\mathrm{a} 4 \mathrm{r}=$ Lichtenberger b6v). Hungary will become subject to a German king who will reconquer Constantinople ( $\mathrm{a} 4 \mathrm{r}=$ Lichtenberger $\mathrm{d} 5 \mathrm{v}$ ). The papal throne will be empty for a time while strife ensues between the German emperor and Rome with its papal court, but peace will be restored by an angelic pope who will cleanse clerical life. Although his reign will last only three years, three more popes of the same quality will follow after him (a4r-v = Lichtenberger g1r-g2v).

The Extract of Various Prophecies introduces a note of urgency at this point by citing the preaching of a prophet in France in 1508 (in "our times," as the Extract adds) from the Speculum of Joseph Grünpeck. ${ }^{9}$ As that prophet had proclaimed, now is the time to wake up, for there is little time left $(\mathrm{a} 4 \mathrm{v}-\mathrm{b} 1 \mathrm{r}=$ Grünpeck a5r-v). All that has been prophesied will surely come to pass (b1r $=$ Grünpeck a8v). People must not ignore the prophet's message, for one fears that this is the time of tribulation and that God has withdrawn his grace from Christian Europe (b1r-b2r = Grünpeck a4r-v). The Turks and Agareni will oppress Christians until a German prince opposes and defeats them, peace will be established under Maximilian, and Constantinople will be reclaimed. But if the German lands and German princes do not support the emperor, then the Turks will lay waste to them until the Turks are finally defeated $(\mathrm{b} 2 \mathrm{r}-\mathrm{b} 2 \mathrm{v}=$ Lichtenberger e4v-e5r). The signs of the time are apparent today, so now is the time to put on the armour of God so that Christendom and the empire will be saved $(\mathrm{b} 2 \mathrm{v}-\mathrm{b} 3 \mathrm{r}=$ Grünpeck b6v).

The Extract of Various Prophecies closes with fifty-four lines of verse about the pervasive corruption of all walks of life and the absence of every virtue (b3r-b4r). This concluding verse is itself an extract from a longer poem of 108 lines. The complete text of this longer poem, entitled "Pretty lovely rhymes together expressing the course of this world" ("Hubsche liebliche Reymen, gemeynigklich außdrucken den lauff diser Welt") was copied onto the final blank pages of the Trias Romana in German translation, a tract excoriating Rome and its inhabitants that was printed in 1519 (VD16 T 1911). By 1520, the pamphlet was bound in a composite volume owned by Stephan Roth, head of

9. Citations of Grünpeck's Speculum refer to the first German edition (VD16 G 3642): Ein spiegel der naturlichen himlischen und prophetischen sehungen aller trübsalen / angst / und not / die uber alle stende / geschlechte / und gemaynden der Christenheyt / sunderbar so dem Krebsen under geworffen sein / und in dem sibenden Clima begriffen / in kurtzen tagen geen werden (Nuremberg: Georg Stuchs, 1508). 
Zwickau's municipal chancery. ${ }^{10}$ The verse was first edited in modern times by Karl Gottfried Scharold in a history of the Reformation in Würzburg; the author does not identify the source, but refers to it as an "almanac poem" "Almanachs Gedicht") from 1508, suggesting that the verse was first published along with an annual prognostication for the year $1508 .{ }^{11}$ The beginning of the 108-line poem is consistent with an astrological source, as it attributes the poet's urge to write to the "art of astronomy": "So kumbt mir offt mancher federkyl / Zu handen von wegen der Astronomeyschen kunst." The combination of astronomical influence and social critique, visible only in the longer version of the poem, provided the thematic similarity that likely motivated the inclusion of an excerpt from this poem in the Extract. The longer poem also clarifies that the injunction to strike dead "Turks, Saracens, and Bohemians" is not the poet's own concluding call for crusade, as it has been understood, but is rather a line spoken by hypocrites who are only interested in profit. ${ }^{12}$

The longer poem is also known from fragments of two printed editions. ${ }^{13}$ The more extensive fragment, now in Augsburg, preserves forty-two lines of verse on what was originally the middle bifolium of the third gathering of an otherwise unknown printed work, quite possibly the same astrological pamphlet known to Scharold. The bifolium was pasted into the back cover of a book printed in 1509 that was in the possession of the Observant Franciscans of Augsburg in the seventeenth century. ${ }^{14}$ In what seems an unlikely coincidence, the leaf pasted into the front cover derives from Eyssenmann's prognostication for 1514, so that the sources for the beginning and ending of the Extract both

10. Jacob Klingner, Minnereden im Druck: Studien zur Gattungsgeschichte im Zeitalter des Medienwechsels (Berlin: Erich Schmidt, 2010), 161-69; Otto Clemen, "Miscellen zur Reformationsgeschichte," Theologische Studien und Kritiken 72 (1899): 268-71.

11. Carl Gottfried Scharold, Dr. Martin Luthers Reformation in nächster Beziehung auf das damalige Bisthum Würzburg historisch dargestellt (Würzburg, 1824), 1:64n1, xx-xxiii (appendix item vi). Both Scharold and Clemen recognized the identity of the longer poem and the closing verse of the Auszug. My thanks to Oliver Duntze (Gesamtkatalog der Wiegendrucke) for his assistance in locating Scharold's work.

12. Talkenberger, 147.

13. Salzburg Universitätsbibliothek M I 480 \#10 and Augsburg Staats- und Stadtbibliothek 4 Med 1284, back cover pastedown.

14. Versehung leib sell eer und gutt (Nuremberg: Wolfgang Huber, 1509). VD16 V 854. Augsburg, Staatsund Stadtbibliothek 4 Med 1284. 
appear as binder's waste in the same volume. This social critical poem circulated widely in the sixteenth century, in some cases in the original longer form and in others mediated by the Extract of Various Prophecies, as it was copied into Swiss and Austrian manuscripts, excerpted in Low German verse collections, and added to a Low German Shrovetide play. ${ }^{15}$ Johannes Praetorius, author of an astrological work published in 1665 (VD17 14:073118R), records a muchedited version of the poem, which he regards as a translation of Ovid, perhaps thinking of the world's decline from a golden age to the age of bronze described in the Metamorphoses. ${ }^{16}$

\section{Prehistory}

Talkenberger's dating of the compilation of the Extract in its present form to $1514-15$ is certainly correct. ${ }^{17}$ The derivation of the introductory passage from Eyssenmann's prognostication for 1514 (which was probably published in late 1513) suggests that 1514 may be somewhat more likely than 1515 as the year of composition.

The simple scenario of a compiler sitting down in 1514 with a copy of Lichtenberger's Prognosticatio and Grüneck's Speculum is troubled, however, by a later work, a pamphlet published in 1532 (VD16 ZV 11958) that combined the Auffahrt Abend prophecy with extracts from Lichtenberger. ${ }^{18}$ The pamphlet's

15. Vienna, Austrian National Library Cod. 10100a, 189r-190r; Künstlike Werltspröke / darinne aller Stende / Natur unde Eigenschop / affgemalet syn ([Lübeck: Johann Balhorn the Elder], 1540), 41r; J. M. Lappenberg, "Eyn nige gedichte rymelick gesettet," Zeitschrift des Vereins für Hamburgische Geschichte 2 (1847): 281-82; J. M. Lappenberg, "Pasquill auf die Vorspraken zu Hamburg," Zeitschrift des Vereins für Hamburgische Geschichte 2 (1847): 566-68; Adalbert von Keller, Fastnachtspiele aus dem fünfzehnten Jahrhundert, Bibliothek des Litterarischen Vereins in Stuttgart 30 (Stuttgart: Litterarischer Verein, 1853), 1475-76; Reinhold Köhler, Kleinere Schriften von Reinhold Köhler (Berlin: E. Felber, 1900), 2:73-79; Wilhelm Mantels, "Niedersächsische Lieder," Zeitschrift des Vereins für Lübeckische Geschichte und Alterthumskunde 1 (1860): 252-53; Ludwig Dietz and Nicolaus Baumann, Die jüngere Glosse zum Reinke de Vos (M. Niemeyer, 1891), 284-87; J. M. von Planta, "Zuozer Stammbuchblätter der Jahre 1572/73," Bündner Monatsblatt 5-6 (1969): 144-45.

16. Johannes Praetorius, Astrologia germanica et germana: Das ist: Eine neu-erfundene Geographische Astrologie (Leipzig: Frommann, 1665), 256-57.

17. Talkenberger, 148 .

18. Reymundus Offenbarung. Ist gefunden worden in aynem alten Buch / Vor vil Jaren geschriben. Die Propheceyen unnd Weyssagungen / so inn unsern zeytten zum tayl erschynen / und noch ergehen sollen / 
title formulation describes a list of prophetic authorities clearly related to the title formulations of the Extract of Various Prophecies ("durch Cirillum / Joachim / Brigitten / Franciscum / Reinhart / unnd Methodium"), but in a different order and with one addition. The pamphlet's second section contains only two passages from Lichtenberger, but these two passages correspond nearly exactly to two sections of the Extract of Various Prophecies, so that it is quite unlikely that the two passages represent an independent borrowing from Lichtenberger. The passages appear in reverse order compared to the Extract (that is, in their original order according to the Prognosticatio: Lichtenberger e4v-e5r, h2r-v). The text of the two extracts shares several innovations with an edition of Lichtenberger printed in 1497 by Bartholomaeus Kistler in Augsburg (ISTC il00209000/GW M18245) and with the Extract of Various Prophecies, most prominently the reference to Maximilian as the firstborn of "Archalyngis" (Lichtenberger 1497), "Archalingie" (1532 pamphlet), and "Archangelis" (Extract) versus the original "Acharlyngis" (Lichtenberger 1490). The 1532 pamphlet and the Extract of Various Prophecies likewise share several innovations not found in printed editions of Lichtenberger, including identifying one Turkish leader as "den Türckischen hund" (1532 pamphlet) and "den Türckischen hundt" (Extract) rather than "doglusum" (Lichtenberger) or "Daglosum" (Lichtenberger 1497). The 1497 edition of Lichtenberger has a number of unique innovations not shared by either the 1532 pamphlet or the Extract, however, and the Extract in turn has numerous textual innovations compared to the 1532 pamphlet and the printed editions of Lichtenberger.

The most parsimonious explanation of these observations is that an edition of Lichtenberger similar to Kistler's Augsburg edition, perhaps its precursor, probably published around 1497 in Augsburg, served as the basis for an extract of prophecies, most likely in manuscript form, that bore the name of several prophetic authorities. This manuscript tradition of extracts from Lichtenberger is the textual origin of both the 1532 pamphlet and the Extract of Various Prophecies. A specimen of this manuscript tradition was reworked and supplemented with texts from Eyssenmann and Grünpeck, probably in 1514, perhaps also in Augsburg. Talkenberger notes that Lichtenberger's and

vonn Türckischen Kaysern / auch sonst anderem gewalt / vor vil Jaren durch Cirillum / Joachim / Brigitten / Franciscum / Reinhart / unnd Methodium etc. beschriben. ([Augsburg: Heinrich Steiner], 1532). 
Grünpeck's views contradict each other in some respects. ${ }^{19}$ But any conflicts between the two need not have troubled the compiler of the Extract because the basis of compilation was not Lichtenberger's complete Prognosticatio, but a selection of prophecies in manuscript.

The existence of a Dutch edition lacking the concluding verse and the prologue from Eyssenmann, and which has been dated to 1509, raises the intriguing possibility that we have a very early and far-flung witness of the early manuscript tradition. ${ }^{20}$ But there is no clear reason to date the Dutch edition to 1509. The Dutch text bears no traces of an earlier textual stage, while it contains all of the innovations found in the German editions of the Extract of Various Prophecies. The Dutch title states that the prophecies will extend to the year 1525 , similar to German editions printed from 1523 to 1524 (VD16 P 4545-47). That the Dutch edition alters the date by which it reckons the world's age from 1515 to 1525 is another reason to date the Dutch edition to around 1523 . While the Dutch edition omitted the preliminary defense of astrology and the concluding verse, it added an additional prophecy against the Jews, similar in a few points to one found in Lichtenberger's Prognosticatio (e5v), but not the same text. The Dutch edition's title woodcut is a horoscope depicting the positions of the seven planets, but with only two of the planets clearly identified, the dating of the woodcut remains uncertain. ${ }^{21}$ The Dutch edition documents the widespread popularity of the Extract but not, unfortunately, its age.

\section{Zwickau}

The decisive year for the Extract of Various Prophecies was not in any case 1514 or 1515 , but 1516 , when six editions were printed by six different printers in four

19. Talkenberger, 145 .

20. Andrew Pettegree and Malcolm Walsby, Netherlandish Books: Books Published in the Low Countries and Dutch Books Published Abroad before 1601 (Leiden: Brill, 2011), 2:1141, no. 26021.

21. One planet, larger than the others and labelled "d," may represent the sun; another crescent labelled "g" likely represents the moon. If one assumes that the letters a-g represent the planets in order from uppermost to lowest, then the planetary configuration is consistent with that of 13 September 1512, but the signs of the zodiac surrounding the planets and designated by the letters A-M are inconsistent with that date. The woodcut is in any case likely to have been reused from an earlier astrological prognostication or may have been purely decorative, with no basis in astronomical observation at all. My thanks to Richard Kremer (Dartmouth University) for his aid in interpreting the woodcut. 
different cities. The title pages of all editions before 1523 incorporate woodcuts of the same scene, in which a large star (likely representing a comet) dominates the centre of the image. Below the star are representations of the solar and lunar eclipses for 1518 and 1519, accurately reflecting the degree of eclipse as found in contemporary astronomical reference works, while personifications of the three upper planets, Jupiter, Saturn, and Mars, and zodiacal signs are arranged above the star.

One person can be identified as the driving force behind the sudden appearance of the Extract: Hans Stainberger, bookseller of Zwickau. Three of the earliest editions, printed by Erhard Oeglin in Augsburg (VD16 A 4441) and Jobst Gutknecht (VD16 ZV 21328) and Adam Dyon (VD16 A 4440) in Nuremberg, close with the line "Hans Stainberger Buchfurer von Zwicken." None of these editions is a copy of any other, and each may be based on the same exemplar. ${ }^{22}$ The title illustrations of each edition are based on different woodblocks, even as each woodcut closely follows the same visual source. The concluding verse in the Extract on the decay of virtue and social order has been attributed to Stainberger personally, but the grounds for ascribing authorship to Stainberger are unknown, and the identification of the concluding verse's source now makes his authorship quite unlikely. ${ }^{23}$ Nor is he likely to have been the compiler of the Extract of Various Prophecies, as the two-year delay between compilation and publication would be difficult to explain if he were. It is unnecessary to see Stainberger as personally involved with the text's creation: what sets the Extract apart from other prophetic compilations is less its text than its publication in numerous printed editions within a few years, and for that, the experience and professional connections of Stainberger were decisive.

Little is known about Stainberger. He does not appear as a publisher of any other work except the three editions of the Extract of Various Prophecies, and there has been uncertainty about his place of operation. In 1509, a "Buchführer Hans Steinberger von Nürnberg zu Eisenach" gave thirty-seven Gulden to a merchant who was later robbed of the money on his way to the Frankfurt trade fair. $^{24}$ If this was the same bookseller, as seems likely, then Stainberger was

22. In the preparations for this article, it was possible to consult copies of all editions of the Extract of Various Prophecies in person or in facsimile with the exception of one edition of 1529 (VD16 A 4446).

23. Robinson-Hammerstein, “The Battle of the Booklets," $137 \mathrm{n} 34$.

24. "Regesten der Landgrafen von Hessen," Landesgeschichtliches Informationssystem Hessen (LAGIS), online, no. 7369, accessed 10 June 2017, http://www.lagis-hessen.de/de/subjects/idrec/sn/lgr/id/7369. 
originally from Nuremberg and active in Eisenach in 1509. If he is designated as "von Zwicken" (modern Zwickau) in the colophons of 1516, it is not because of his birth there, but because that town had become the centre of his merchant activity. Stainberger's bookselling activity in Zwickau between 1524 and 1531 is attested in letters to Stephan Roth, mentioned above as the owner of the composite volume in which the 108-line version of the concluding verse was recorded; in 1527, Roth would provide a new and more modern translation of Lichtenberger's Prognosticatio with a foreword by Martin Luther that was published by Hans Lufft (VD16 L 1597). In the letters addressed to Roth, Stainberger does not always appear in a positive light. Two writers complain to Roth about the bookseller's "precipitous and inconstant spirit" and his habit of making sudden and unannounced departures. Valentin Hertel, a teacher in Zwickau, had wanted Stainberger to bring a letter to Roth, but learned of Stainberger's departure from town only when he saw the bookseller sitting on a saddled horse..$^{25}$

The decisive role of a Zwickau bookseller in the publication of the Extract of Various Prophecies in 1516 raises the question of possible connections between the pamphlet and the outbreak of radical prophetic preaching in Zwickau four years later. In 1520, Thomas Müntzer was appointed to a preaching office in Zwickau, where he remained until he was expelled from town in April 1521. ${ }^{26}$ His next station was Prague, where his failure to find a receptive audience led him to write his unpublished Prague Manifesto before his expulsion from that city as well in December 1521. Müntzer would go on to become a spiritual advisor to the revolt of the German peasants, and was beheaded in 1525 in the wake of their defeat. Certainly, Müntzer espoused some beliefs similar to what can be found in the Extract of Various Prophecies. Müntzer's preaching was apocalyptic and urgent, and he emphasized the superiority of direct divine revelation over written texts, including scripture. In the Prague Manifesto, Müntzer foresaw a climactic battle against the Turks for the next year, and he warned his audience that they would face destruction by the Turks if they ignored him, much as the Extract foresaw the Turks destroying German princes

25. Georg Buchwald, "Stadtschreiber M. Stephan Roth in Zwickau in seiner literarisch-buchhändlerischen Bedeutung für die Reformationszeit," Archiv für Geschichte des deutschen Buchhandels 16 (1893): 6-246, no. 53 (pp. 38-39).

26. Tom Scott, Thomas Müntzer: Theology and Revolution in the German Reformation (New York: St. Martin's, 1989), 17-44. 
who failed to support the emperor $(\mathrm{b} 2 \mathrm{r}-\mathrm{b} 2 \mathrm{v}) .{ }^{27}$ In his support for the Peasant's War, Müntzer did all he could to bring about a confederation of the peasants and commoners against the powerful and the nobles, the fall of princes, and the poverty of the clergy, just as the Extract had predicted for the years after 1522 (a3r). Yet Müntzer was far too broadly read for one pamphlet to be decisive in his thought. Preserved book lists attest a personal library in which humanists, medieval German mystics, and the present controversies in theology were well represented. ${ }^{28}$

While in Zwickau, Müntzer had become acquainted with the visionaries today known as the "Zwickau prophets," including Nikolaus Storch, Thomas Drechsel, and Marcus Stübner. ${ }^{29}$ Like Müntzer, the Zwickau prophets saw themselves as recipients of visions that they were to proclaim to the people, and they regarded divine revelation as superior to scripture. ${ }^{30}$ Identifying the exact teachings of the Zwickau prophets presents some difficulties, as we are dependent on the accounts of their opponents. Storch was said, like the Extract, to predict an imminent invasion by the Turks, who would conquer the German lands to the detriment of sinners and the impious; the clergy would be persecuted before Christian unity would be restored. ${ }^{31}$ The Zwickau prophets welcomed Martin Luther's reforms, but saw him as only the herald of a greater reformer to come, much as the Extract of Various Prophecies treats reform in several passages that can be read as an unfolding and acceleration from one to the next $(\mathrm{a} 3 \mathrm{r}-\mathrm{a} 3 \mathrm{v}, \mathrm{a} 4 \mathrm{v})$. Storch was even said to claim the role of divine reformer for himself. Revelations and visionary preaching were not limited to Storch's inner circle, but were said to extend to many of his followers. A Zwickau preacher, Nicolaus Hausmann, complained to the city council that unlearned people among Storch's followers were attempting to write a heretical

27. Thomas Müntzer, “The Prague Protest”, in The Radical Reformation, ed. and trans. Michael G. Baylor (Cambridge: Cambridge University Press, 1991), 1-10.

28. George Huntston Williams, The Radical Reformation (Kirksville, MO: Truman State University Press, 2000), 121-22; Scott, 9-13, 27.

29. Thomas Kaufmann, Thomas Müntzer, “Zwickauer Propheten” und sächsische Radikale: eine quellenund traditionskritische Untersuchung zu einer komplexen Konstellation (Mühlhausen: Thomas-Müntzer Gesellschaft, 2010), 75-86; Williams, 123-25.

30. Paul Wappler, Thomas Münzer in Zwickau und die "Zwickauer Propheten" (Zwickau: Realgymnasium, 1908), 12.

31. Wappler, 19-20, 28. 
booklet. The council consequently authorized Hausmann to test the orthodoxy of the would-be writers. ${ }^{32}$ In contrast, Marcus Stübner, who had studied in Wittenberg and was already known to Melanchthon, was asked by the theology faculty in Wittenberg if he had written any books, but he is reported to have said that God had forbidden him. ${ }^{33}$ Storch and his companions undertook a journey to Wittenberg in December 1521, where they initially made a positive impression on Melanchthon and others but were eventually firmly rejected by Luther. Shortly after, the paths of the Zwickau prophets became lost to history. ${ }^{34}$ Any influence of the Extract of Various Prophecies on the Zwickau prophets must remain hypothetical, as their teachings are too poorly preserved, and there were numerous other sources from where they could have learned the apocalyptic motifs shared with the Extract. And yet taken together, the actions of Hans Stainberger as publisher, Thomas Müntzer as preacher, and Storch and his followers as prophets illustrate a belief in concrete manifestations of prophecy and apocalypse in Zwickau and surrounding regions prior to and following the onset of the Reformation.

\section{Wittenberg}

The Extract of Various Prophecies eventually did make its way to Wittenberg, but its path was indirect and marked by conflict. In 1525, the Nuremberg printer Hans Hergot republished the Extract (VD16 A 4443), choosing a title page that eschewed eclipses and anthropomorphized planet-gods in favour of more direct depictions of apocalyptic events. In Hergot's edition, the title woodcut shows an army on horseback led by the crowned emperor routing an army of turbaned riders. The emperor's lowered lance pierces the leader of the enemy force, while the rest are fleeing the battlefield. In the background, an astrologer consults an astrolabe as he gazes into a sky filled with a comet or star and an eclipse in the sign of Cancer. The astrologer turns his back on the battle taking place behind him, which he presumably has already seen foretold in the heavens. This woodcut appeared again in the last two editions of the Extract printed in Nuremberg in 1540 (VD16 A 4433-4434).

32. Wappler, 21-22.

33. Wappler, 28.

34. Wappler, 25-26. 
Hergot's text includes an extremely unusual addition, as Talkenberger recognized..$^{35}$ Following the conclusion of the Extract of Various Prophecies, a new voice adds its own response to the preceding collection of prophecies. After the Extract concluded that the time would soon be at hand when its prophecies would be fulfilled and that disaster would strike all who do not repent, Hergot's new conclusion ( $\mathrm{clv}-\mathrm{c} 3 \mathrm{r}$ ) laments that the predicted events and signs of the times are already coming to pass, and yet people continue to ignore the prophecies despite their obvious fulfillment. The new conclusion also records the author's own revelatory moment:

I saw a star in the sky shining as bright as day, and my heart was afraid, and I thought, "God, what do you intend to do?" Then it became as bright as day even though it was midnight. A bright star burned like the sun, and many small bright stars went forth from it. The everlasting God who placed them in heaven knows what they mean; I don't know what it means. I would like to say that great lords who make themselves brighter than daylight will pass away with all their pomp. They ignore the fact that day shines even brighter than they do. ${ }^{36}$

With even sharper criticism of political leaders, the new conclusion identifies oppressive rulers as the real Turks who are to be utterly defeated within two years, as the Extract predicts. The conclusion sees the awful punishment recently inflicted on the peasants as their just reward for trying to usurp the rulers' place, but also calls on rulers to exercise justice and mercy towards the peasants.

Two years later, Hergot was executed in Leipzig for his role in publishing a utopian-revolutionary tract, which in the nineteenth century was identified

35. Talkenberger, 150-52.

36. Eyn außzug etlicher und Propheceyen auff vergangne vnd zůkünffige Jar / Sybille / Brigitte / Cirilli / Joachim des Abts / Methodii und brüder Reinharts / wirt weren biß auff das M.D.lxxxi. Jar (Nuremberg: Hans Hergot, 1525), c1v-c2r: "Ein Stern sach ich am himel stan / der leüchtet her recht wie der tag / und meyn hertz erschrack / und ich gedacht / Got / was wiltu machen / do ward es liechter tag / und was zu mitternacht / ein heller stern / bran als die sunn / und von im giengen vil der kleynen und hellen stern / Was sie bedeuten / das weys der ewig Got / der sie an den hymel gestellt hat / ich weys nit was er bedeut / ich möchte sprechen / das die grossen herschafft zergehen würden / mit allem irem pracht / die sich doch grösser machen wenn der tag / und der tag scheyne doch heller / das bedencken sie nit." 
as Von der newen wandlung eynes Christlichen lebens (VD16 V 2614). ${ }^{37}$ Hergot's authorship of this tract has been disputed, but Frank Ganseuer has argued that Hergot's authorship is entirely plausible due to Hergot's many personal and professional contacts with religious radicals and his manifest sympathy with their views, as attested by his publication program..$^{38}$ One additional relevant element in Hergot's publication program is surely his edition of the Extract of Various Prophecies, and the same observation concerning Hergot and the authorship of the utopian tract could also be made about the new conclusion of the Extract: the Nuremberg radicals with whom Talkenberger associates authorship of the new conclusion were all associates of Hergot mentioned by Genseuer in arguing for Hergot's authorship of the utopian tract of $1527 .{ }^{39}$

Even after Hergot's execution in Leipzig, the radical addition to the Extract of Various Prophecies did not prevent a Leipzig printer, Nickel Schmidt, from printing three editions of Hergot's expanded text in 1526-29, although he returned to the original style of title woodcut (VD16 A 4444, A 4432, and A 4446). Schmidt added his own expansion to the text by inserting a short prediction of decline and decadence in monastic life taken from the "Thirteenth Sibyl," a work published as part of a sibylline compilation in 1516 (VD16 ZV 11992) and by itself around 1518 (VD16 S 6274-6275).

One of Schmidt's editions in turn served as the basis for the Extract of Various Prophecies when it was finally published in Wittenberg by Georg Rhau in 1530 (VD16 ZV 17958). Rhau's edition omitted the introduction and both the original conclusion and Hergot's conclusion, replacing them with introductory and concluding texts of its own. Like Hergot's conclusion, these new paratexts observe that many prophecies in the Extract have already been fulfilled. Rhau's introduction names the Peasant's War and the fall of Hungary to the Ottoman Turks as specific examples. Rhau combined the Extract of Various Prophecies with Johann Carion's Interpretation and Revelation, a series of astrological predictions for each year until 1540 and one of the most popular astrological

37. Hans Hergot, "On the New Transformation of the Christian Life," in The Radical Reformation, ed. and trans. Michael G. Baylor (Cambridge: Cambridge University Press, 1991), 210-25; on Hergot, see Carola Schelle-Wolff, Zwischen Erwartung und Aufruhr: die Flugschrift "Von der newen wandlung eynes Christlichen lebens" und der Nürnberger Drucker Hans Hergot (Frankfurt: Lang, 1996), 11-128.

38. Frank Ganseuer, "Hans Hergot und der 'linke Flügel der Reformation' in Nürnberg," Mitteilungen des Vereins für Geschichte der Stadt Nürnberg 71 (1984): 165-66.

39. Talkenberger, 151; Ganseuer, 159-66. 
works of the time, just as Carion was at the height of his fame. Carion would later complain bitterly about the combination of his sober-minded astrology with the "dreams of monks, Lollards, or nuns" and "loose scraps from Lolhart, Birgitta, Methodius and so on, whom I have abhorred for my whole life," although Carion's complaint was not entirely valid-Carion had earlier cited prophecies from Methodius, Hildegard of Bingen, and Joachim of Fiore in his own prognostication for the year $1524 .^{40}$

\section{Speyer}

Carion's indignation was not the only time the Extract of Various Prophecies attracted controversy. After 1518, five years passed before the next edition was printed, this time by Johann Lobmeyer in Würzburg (VD16 P 4545), who maintained a small workshop primarily in the service of the episcopal court. Just twenty editions are known from Lobmeyer's press between 1518 and 1525, all of them smaller booklets, nearly all of them in German - and, in 1524 and later, surprisingly many works promoting the Reformation. Lobmeyer even printed the peasants' twelve articles after their army had been defeated, although it had taken control of Würzburg for a time and besieged the fortress overlooking the city; Gisela Möncke sees this as Lobmeyer's decisive transgression, ending his privilege as court printer. $^{41}$

When Lobmeyer printed his edition of the Extract of Various Prophecies, he made few changes to the original text, but he altered the beginning of the title to Practica teutsch auff Das XXiiii. und Funfundzwanzigest Jar, so that it resembled the title of an astrological prognostication for 1524-25. He also chose an entirely new title image that connected the Extract to a matter of urgent controversy: the widespread rumour that the planetary conjunctions of 1524 predicted a second, world-ending deluge. ${ }^{42}$ In the title woodcut, Venus and Saturn in anthropomorphic form and a fish representing Pisces surround

40. On this incident involving Carion and the Extract of Various Prophecies, see Jonathan Green, Printing and Prophecy: Prognostication and Media Change 1450-1550 (Ann Arbor: University of Michigan Press, 2012), 57-59.

41. Gisela Möncke, "Zum Würzburger Buchdruck in der ersten Hälfte des 16. Jahrhunderts: Johann Lobmeyer-Balthasar Müller-Melchior Bopp," Archiv für Geschichte des Buchwesens 62 (2008): 155.

42. On this controversy, see Talkenberger, 154-335; Mentgen, 135-55; Green, Printing and Prophecy, $131-50$. 
a radiant comet, while in the unhappy landscape below, a downpour raises a torrent of water that engulfs cities and the luckless people being carried away in the flood.

When a printer farther west in Speyer, Jakob Schmidt, twice reprinted the Extract of Various Prophecies the next year (VD16 P 4546-4547), he used a copy of Lobmeyer's edition as his exemplar, but Jakob Schmidt eliminated the specific reference to 1524 and 1525 from the title and used different title woodcuts. In one, Saturn and Venus still surround a radiant star in the sky, but Pisces and the depiction of flooding have entirely disappeared. In the other edition, only the identification of Venus and Saturn as "rulers of this year" on the title page allude to the typographic conventions of annual prognostications; the woodcut page borders are entirely generic. At the time that Jakob Schmidt printed the Extract, his publication program was weighted heavily towards proReformation works in a town that was still debating its religious allegiance and would ultimately side with the old faith. ${ }^{43}$ We may surmise that the Extract represented a rare opportunity for Jakob Schmidt, as it allowed him to reprint a prophecy of religious reform, renewed clerical poverty, and a campaign against the pope by the German emperor that had previously been printed by the court printer to the bishop of Würzburg.

Jakob Schmidt's editions of the Extract of Various Prophecies did not go unanswered, although the answer came from the Lutheran side. ${ }^{44}$ Heinrich Pastoris's polemic (VD16 P 900-02) was directed specifically against the renewed printing of an "extract from the prophecy of Sibilla, Brigitta, Cyril, Joachim, and Methodius the Abbott, which was printed in Speyer." ${ }^{45}$ Pastoris saw the Extract as leading simple people away from the clear Word of God.

43. On Schmidt, see Josef Benzing, "Jakob Schmidt zu Speyer (1514-1536?) und seine Drucke," Gutenberg-Jahrbuch 30 (1955): 114-25; Josef Benzing and Christoph Reske, Die Buchdrucker des 16. und 17. Jahrhunderts im deutschen Sprachgebiet (Wiesbaden: Harrassowitz, 2007), 846-47.

44. Talkenberger, 308-11; Robin B. Barnes, Astrology and Reformation (New York: Oxford University Press, 2015), 121-22; Heinrich Pastoris, Practica Teütsch: Casting a German Horoscope, ed. and trans. Helga Robinson-Hammerstein (Dublin: Friends of the Library, Trinity College, 1980).

45. Heinrich Pastoris, Practica deutsch von vergangen / und zن kunffigen dingen wider die ż Speyer gedruckt auß der heiligen schrifft gegründt und getzogen (Erfurt: Michel Buchfürer, 1523), a1v: "einn außzug aus der prophecey Sibille / Brigitte / Cirille / Joachim / des abts Methodii / der selbige zu Speyer gedruckt / als der Tyttel anzeiget." The date of the dedicatory epistle is Sunday after the feast of St. Michael [4 October] 1523, so if Pastoris was referring to one of the known Speyer editions, both dated to around 1524, then either one or both must have been printed by September 1523. 
Talkenberger and Robin Barnes have recognized how Pastoris reused typical apocalyptic motifs while giving them a new Lutheran meaning, and how Pastoris presented his own work, based on scripture, as the true prognostication of things to come in place of the Extract and other astrological or prophetic pamphlets. ${ }^{46}$ What has been overlooked, however, is how much of Pastoris's rhetoric specifically echoes the language of the Extract of Various Prophecies itself. In the Extract, the Agareni are foreign oppressors; Pastoris explains that they are to be understood as proponents of Catholic teaching. Pastoris presents Martin Luther as the true heavenly reformer and Frederick of Saxony as the true divine emperor. The call for the German princes to support the emperor in the Extract has a counterpart in Pastoris's call for lords and princes to accept the Reformation, while the urgent note of warning in the Extract of Various Prophecies finds its parallel in Pastoris's call for readers to clothe themselvesnot in the armour of God, as the Extract does, but in Christ's swaddling clothes. Pastoris may have regarded the Extract of Various Prophecies as devilish, but it was devilish in a way that could be made useful to Lutheran ends.

\section{Strasbourg}

By 1517-18, the Extract had made its way to the western printing centres of Strasbourg and Cologne. A Nuremberg edition (VD16 A 4438) had served as the exemplar for a now lost edition that had added a prophecy attributed to Birgitta of Sweden excerpted from Lichtenberger $(\mathrm{c} 1 \mathrm{v}-\mathrm{c} 2 \mathrm{r})$ and added Lichtenberger to the list of prophets named in the title, as well as introducing some changes to the text. This lost edition then served as the basis for a Low German edition published in Cologne (VD16 A 4447) and for an edition published by Reinhard Beck the Elder in Strasbourg. ${ }^{47}$ Beck's text was thoroughly revised, and he retitled his edition as a "New Extract of Various Prognostications and Prophecies" (VD16 A 4439).

Beck's publication of the Extract of Various Prophecies in Strasbourg shortly before 1520 is intriguing, as Strasbourg was the centre of another circle of prophetic nonconformists, the Strasbourg prophets, foremost among

46. Talkenberger, 309; Barnes, Astrology and Reformation, 122.

47. On the Cologne edition, see Conrad Borchling and Bruno Claussen, Niederdeutsche Bibliographie: Gesamtverzeichnis der niederdeutschen Drucke bis zum Jahre 1800, vol. 1 (Neumünster: Wachholtz, 1931), col. 278 (no. 608). 
them Lienhard and Ursula Jost. The Josts and their prophetic peers became associated with Melchior Hoffman soon after his arrival in Strasbourg in $1529 .{ }^{48}$ The prophetic awakening of the Josts had begun already by the end of 1522, however, long before Hoffman's arrival.

It seems scarcely probable that Jost can be regarded as a reader of the Extract, as Hoffman attests that Jost was an illiterate labourer. ${ }^{49}$ And yet it is also quite clear that Jost was a participant in the print-mediated public debates of the time. The two concerns that motivated his first visionary experience of December 1522 were the Reformation, or in Jost's own words the controversy over the "honor of the saints and the other articles that are now at hand," and the "great flood that according to many people is to come over us." 50

While Jost may have heard oral accounts of the Reformation and the predicted flood, it is clear that Jost was also reading printed works, even if his mode of reading did not take the form of decoding letters or words. Soon after the beginning of his ministry, Jost felt divinely compelled to throw off his clothes and walk naked into Strasbourg, shouting out his message as he went, which promptly landed him in the city's asylum. On 1 January 1523, while still in the asylum, Jost shouted, "You dear Christians, may God give you all a blessed new year" ("Ir lieben Christen Got geb euch allen ein new sellich Jor"). Jost then called on everyone to throw off their stinking clothes, and he added, "He is naked and bare so that he does not find us unclean, for he has chosen your city for his own." ${ }^{51}$ In this incident, Jost was echoing the language of almanacs and annual prognostications, often including depictions of the naked Christ child and phrases such as "A blessed New Year" ("ein gut seliges neues Jahr"), that were customarily presented as gifts as part of the New Year celebration. On the first day of 1523, Jost turned himself into a prophetic living tableau based on the texts and woodcuts that often appeared on the title pages of astrological booklets. It is impossible to know if Lienhard Jost knew the Extract of Various Prophecies, but it is clear that pamphlets like it were the

48. Klaus Deppermann, Melchior Hoffman: Social Unrest and Apocalyptic Visions in the Age of Reformation (Edinburgh: T. and T. Clark, 1987), 160.

49. Jonathan Green, “The Lost Book of the Strasbourg Prophets: Orality, Literacy, and Enactment in Lienhard Jost's Visions," Sixteenth Century Journal 46 (2015): 317.

50. Lienhard Jost, Ein worhafftige hohe und feste Prophecey, ed. Melchior Hoffman (Deventer: Albertus Paffraet, 1532), b1r.

51. Green, "Lost Book of the Strasbourg Prophets," 324. 
part of the print ecosystem he was closest to, and that their contents entered his consciousness in oral and visual form.

In 1530, Hoffman published the visions of Ursula Jost anonymously. The printer for this edition was Balthasar Beck, married since 1527 to the widow of Reinhold Beck the Elder. During his career, Balthasar Beck printed several works by Hoffman and other religious radicals and nonconformists. ${ }^{52}$ The Strasbourg city council took offense at the publication of Ursula Jost's visions, however, and resolved to interrogate and appropriately punish Hoffman, the anonymous female author, and the printers involved. At the hearing in April 1530, Balthasar Beck and another printer, Christian Egenolff, denied all knowledge of Hoffman or "his woman."53

Beck remained in Strasbourg, but by September 1530 Egenolff had left Strasbourg and set up a new workshop in Frankfurt. The next year, Egenolff began printing a collection of sibylline prophecies supplemented with additional prophetic works, joined, beginning in 1532, by a long excerpt from the Extract of Various Prophecies. As a basis for the excerpt, Egenolff used the revised text of the "New Extract" that had been printed by Reinhard Beck in Strasbourg in $1518 .{ }^{54}$ Inclusion in Egenolff's frequently reprinted sibylline collection ensured the continued reprinting of the Extract for the next two centuries, appearing as late as ca. 1750, where it comprises the majority of a collection entitled Die Holländische Sibillen Weissagung (VD18 1188259X).

\section{Conclusions}

By 1548, Egenolff was including an excerpt of the Extract of Various Prophecies as part of a more extensive prophetic collection that included the entire Prognosticatio of Johannes Lichtenberger. Such associations between Lichtenberger's full Prognosticatio and the Extract based on it were not uncommon. Heinrich Steiner's edition of the Extract of Various Prophecies, printed in 1527 in Augsburg (VD16 A 4442), reverted the reference to Maximilian's sire to "Acharlingis," showing that an editor knew the source of

\section{Benzing and Reske, 881.}

53. Manfred Krebs and Hans Georg Rott, eds., Quellen zur Geschichte der Täufer, VII. Band: Elsaß, I. Teil. Stadt Straßburg 1522-1532 (Gütersloh: Gerd Mohn, 1959), 261-62 (nos. 211-12).

54. On the development of Egenolff's compilations, see Green, Printing and Prophecy, 102-08. 
the Extract and referred back to it for corrections. Rhau's Wittenberg edition that combined the Extract of Various Prophecies with Carion's astrological work illustrated the Extract with the same woodcuts used to illustrate an edition of Lichtenberger's Prognosticatio. As noted above, several of the redactors of the Extract of Various Prophecies returned to the Prognosticatio for additional prophetic excerpts. While Heinrich Pastoris may have decried the anonymity of the Extract, the relationship to the Prognosticatio was not unknown. Thus, it will not do to refer to the Extract as the "Anonymous Practica," a misleading designation and an unnecessary invention for a work that did not lack a title. The original title formulation of the Extract is quite correct and was well understood by contemporaries; in this booklet, one would find extracts of various practicasannual astrological prognostications, including Eyssenmann's prognostication for 1514 and another for 1508-along with excerpts of various prophecies, including excerpts from Lichtenberger and from Grünpeck. Anonymity does not distinguish the first compiler of the Extract from the later redactors, none of whom are known for certain, or from the compilers of other contemporary prophetic pamphlets.

What do all these observations of the Extract of Various Prophecies, all these wobblings of a magnetized needle, so to speak, tell us about prophecy on the eve of the Reformation and in its earliest phase? As noted at the outset, the paths of prophecy are often subterranean, so that the connections between prophetic texts, between texts and preaching, or between prophetic visionaries often remain outside our view. It is clear, however, that the Extract was itself one of the subterranean streams by which apocalyptic motifs spread in Reformation Germany. The Extract linked late medieval prophecies as collected by Lichtenberger with Reformation-era apocalypticism and, in later decades, with prophecies printed as popular chapbooks. The diffusion of apocalyptic motifs took multiple paths, but an important path consisted of inexpensive pamphlets like the Extract.

The composition and circulation of the Extract of Various Prophecies underline how narrow the gap was between religious apocalypticism, popular prophecy, and learned scientific astrology. The introduction and the concluding verse of the Extract were taken from astrological booklets, and its primary source, Lichtenberger's Prognosticatio, was already an amalgam of prophetic and astrological texts. While the title formulation of the Extract emphasized the prophetic in listing its sources by name, the title page woodcut, with its 
depiction of planets, eclipses, and Zodiac signs, emphasized the astrological. The Extract was reprinted in combination with both prophetic texts and astrological prognostications, and the moment of prophetic inspiration described in the new conclusion of Hans Hergot's edition is mediated by the author's observation of the stars. The distinction between rational astrology and superstitious prophecies so important to Carion and university-affiliated astrologers, and the distinction between devout reading of the Apocalypse and godless reckoning of the heavens so important to some churchmen, were lost on many readers of the Extract and similar Reformation-era pamphlets.

As conveyors of Reformation-era prophecy, oral and print media had different impacts. Prophecy as text, even amplified by the printing press, did not present nearly the challenge to the Reformation as did prophetic preaching rooted in the idea that all believers could receive divine revelation. ${ }^{55}$ As the case of Heinrich Pastoris shows, an objectionable prophetic text can be reinterpreted, co-opted, or made to serve an amenable purpose. This was also Luther's approach to Lichtenberger's Prognosticatio. Although Luther regarded astrology as an unreliable and devilish art, he admitted in the preface he wrote for a 1527 edition of the Prognosticatio that some of the prophecies had hit close to the target, and he recast Lichtenberger's depiction of society to his own ends. ${ }^{56}$

Prophecy is not only a textual genre, but also a manner of speaking and preaching. Of particular importance for the early modern period is prophecy's ability to legitimize the preaching and publishing of people who would otherwise accept their own silence. In Zwickau, the acceptance of visionary experience encouraged writing from a new group of would-be authors among followers of Nikolaus Storch, in contrast to the literary silence of the visionary but university-trained Marcus Stübner. In Strasbourg, the illiterate Lienhard and Ursula Jost both succeeded in having their visions published. The example of Lienhard Jost suggests that the print media network of the Reformation era reached all social strata of German society, including the uneducated and impoverished. Lienhard Jost may not have been a regular consumer of printed texts, but he occupied a media space within range of broadsides and inexpensive

55. Robin Barnes, "Images of Hope and Despair: Western Apocalypticism: Ca. 1500-1800", in The Encyclopedia of Apocalypticism, ed. Bernard McGinn, vol. 2 (New York: Continuum, 1999), 150.

56. Aby Warburg, Heidnisch-antike Weissagung in Wort und Bild zu Luthers Zeiten (Heidelberg: Carl Winter, 1920), 81-86; Green, Printing and Prophecy, 74-75. 
pamphlets. Jost would normally have been a passive recipient, participating at most through oral discussions with close acquaintances, until the burden of prophecy compelled him to try public preaching, singing in the cathedral, and ultimately print publication. While attempts of unlearned people to write or publish were a cause for concern, early modern civic administrators had the means to observe, investigate, and control such activities, and respond if necessary, as the municipal authorities in Zwickau and Strasbourg did.

To publish a compilation of prophetic texts and sell them to a curious public is one thing, while rising up to preach the word of God as received in dreams or visions would seem to be something of a very different kind. At first glance, visionary preaching seems to be entirely original, an overflowing of divine inspiration or pure genius. For Reformation-era prophetic booklets, we have what seems an entirely different process of circulation, revision, and the accumulation of textual changes, processes that seem entirely derivative. And yet prophetic preaching and prophetic texts are in fact connected. The new conclusion in Hans Hergot's edition of the Extract recorded a case of revelatory vision mediated by the heavens but in response to a printed text, and we find intertextuality even in the oral preaching of visionary prophets. When Melchior Hoffman published the visions of Ursula and Lienhard Jost in 1532 (VD16 XL 156), Hoffman added additional prophecies preached by others in and around Strasbourg, including a prophecy by "Bundt Hans." Although Hoffman recorded this prophecy as the words of an oral preacher, it includes a line exactly as printed in an edition of Dietrich von Zengg, a prophetic pamphlet then in circulation. ${ }^{57}$ Visionaries were interpreting their experiences, and those experiences included the consumption of printed prophetic booklets.

The most significant impact of prophetic booklets like the Extract of Various Prophecies on Reformation-area prophecy lies not in specific influence on particular authors, but in the formation of an audience for prophecy and the shaping of expectations concerning apocalyptic preaching. The publication of the Extract of Various Prophecies by a Zwickau bookseller is less telling for the particular beliefs and attitudes of the city's prophetic preachers than it is for understanding the context of prophetic expectation in which Thomas Müntzer and the Zwickau prophets could find a ready audience for their preaching. Hans Stainberger knew his customers, and his commissioning of at least three 
pamphlet editions of the Extract in 1516 is strong evidence that there was a broad market for apocalypticism in pamphlet form on the eve of the Reformation. In this examination of the transmission of the Extract, we have seen the influence of several figures associated with religious radicalism (Hans Hergot, Balthasar Beck, perhaps Christian Egenolff as well) and agitation for religious reform (Johann Lobmeyer, Jakob Schmidt). Even as we must depend on guilt by association to divine their true convictions, it is clear that the decisive moments in transmission of the Extract of Various Prophecies came not as authors selected motifs in composing texts, but as printers and publishers selected titles for their publication programs and wares for their business dealings. These were people who knew their markets and their customers' tastes, who had connections to major print centres and smaller towns, and who commanded the high ground over the flow of information in the age of print. 


\section{Appendix: Editions of the Extract of Various Prophecies}

(Not including excerpts of the Extract in other works)

$\begin{array}{llll}\text { VD16 } & \text { Year } & \text { Place } & \text { Printer } \\ \text { A 4435 } & 1516 & \text { Augsburg } & \text { Hans Froschauer } \\ \text { A 4436 } & 1516 & \text { Erfurt } & \text { Matthes Maler } \\ \text { ZV 936 } & 1516 & \text { Leipzig } & \text { Martin Landsberg } \\ \text { A 4440 } & {[1516]} & \text { [Nuremberg] } & \text { [Adam Dyon] } \\ \text { A 4441 } & {[1516]} & \text { [Augsburg] } & \text { [Erhard Oeglin] } \\ \text { ZV 21328 } & {[1516]} & \text { [Nuremberg] } & \text { [Jobst Gutknecht] } \\ \text { A 4438 } & {[1517]} & \text { [Nuremberg] } & \text { [Jobst Gutknecht] } \\ \text { A 4447 } & {[1517]} & \text { Cologne } & \text { [Arnd von Aich] } \\ \text { ZV 934 } & {[1517]} & \text { [Nuremberg] } & \text { [Jobst Gutknecht] } \\ \text { A 4439 } & {[1518]} & \text { [Strasbourg] } & \text { [Reinhard Beck the Elder] } \\ \text { P 4545 } & {[1523]} & \text { [Würzburg] } & \text { [Johann Lobmeyer] } \\ \text { (NB 26021) } & {[1523]} & \text { [Dutch] } & \\ \text { P 4546 } & {[1524]} & \text { Speyer } & \text { Jakob Schmidt } \\ \text { P 4547 } & {[1524]} & \text { Speyer } & \text { [Jakob Schmidt] } \\ \text { A 4443 } & 1525 & \text { Nuremberg } & \text { Hans Hergot } \\ \text { A 4444 } & 1526 & \text { [Leipzig] } & \text { [Nickel Schmidt] } \\ \text { A 4432 } & 1527 & \text { [Leipzig] } & \text { [Nickel Schmidt] } \\ \text { A 4442 } & 1527 & \text { [Augsburg] } & \text { [Heinrich Steiner] } \\ \text { ZV 935 } & {[1527]} & \text { [Bamberg] } & \text { [Georg Erlinger] } \\ \text { A 4446 } & {[1529]} & \text { [Leipzig] } & \text { [Nickel Schmidt] } \\ \text { A 4433 } & {[1540]} & \text { [Nuremberg] } & \text { [Georg Wachter] } \\ \text { A 4434 } & {[1540]} & \text { [Nuremberg] } & \text { [Georg Wachter] } \\ & & & \end{array}$


